\title{
Application of Sports Multimedia Network Platform under the Background of Internet +
}

\author{
Chen Li, Mingyuan Zhao, Yiyuan Yang \\ School of Physical Education and Health, Zhaoqing University, Zhaoqing, Guangdong, 526061, China \\ Zhaoqing Education Development Research Institute Project in 2019: Project number: ZQJYY2019041 \\ Guangdong Provincial Education Department epidemic special topic in 2020: Project number:KZDZX1212 \\ Youth Project of Zhaoqing University Research in 2019: \\ Project number:201920
}

\begin{abstract}
With the development of information technology, multimedia technology has been widely used in various disciplines, and has achieved very good results in actual teaching, effectively improving the quality of teaching. The application of multimedia teaching in college physical education is a typical example. Teachers can present the demonstration and imitation of physical education by means of multimedia display, which can effectively improve the efficiency and enthusiasm of students in learning. This article focuses on the application of multimedia network teaching platform and physical education, aiming to better improve the quality of physical education in colleges and universities and improve students' sports ability.
\end{abstract}

Keywords: Internet+; College Sports; Online Teaching Platform; Application

Physical education in colleges and universities is a subject that emphasizes both theoretical study and extracurricular practice. Students need to actively participate in practical teaching activities under the guidance of teachers, which has higher requirements for students' practice. Traditional physical education in colleges and universities is mainly based on outdoor sports practice activities, ignoring the study of theoretical knowledge, and students are not interested in boring sports theoretical knowledge. The rise of Internet multimedia technology has effectively changed this situation and made physical education more Diversification and effective expansion of teaching content greatly enhance the effectiveness of college physical education. Combining many years of college physical education experience, the author analyzes the application of sports multimedia network platform in actual teaching under the background of "Internet +" from the actual teaching situation, and provides some suggestions and opinions for the majority of college physical education teachers in improving the quality of physical education.

\section{Shortcomings in traditional physical education teaching in colleges}

combined with many years of college physical education experience, there are many shortcomings in traditional college physical education, which seriously affect the sound development of physical education. First of all, the teaching concepts of physical education teachers in colleges and universities are too old, their own teaching level is limited, they can't adapt to the new teaching concepts well, and they can't apply some new teaching methods and techniques flexibly. Secondly, college physical education is restricted by traditional teaching methods. Teachers habitually use the concept of test-oriented education. The main goal of the overall curriculum is to improve students' physical test scores. It ignores the cultivation of students' individualization, and does not enhance students' enthusiasm for sports learning, which seriously hinders students' all-round development. Finally, there are also problems in teaching details and re-

Copyright $($ C 2020 Chen Li et al.

doi: 10.18282/le.v9i7.1455

This is an open-access article distributed under the terms of the Creative Commons Attribution Non-Commercial License

(http://creativecommons.org/licenses/by-nc/4.0/), which permits unrestricted non-commercial use, distribution, and reproduction in any medium, provided the original work is properly cited. 
source allocation. Due to the limitations of sports venues and insufficient basic hardware equipment in some universities, the effectiveness of physical education in colleges and universities is greatly restricted. In the process of specific theoretical explanations, students cannot be more intuitively understood, resulting in limited specific teaching effects. , Making the development of college physical education limited.

\section{The design and application of college sports multimedia network teaching platform under the background of "internet+"}

Traditional college physical education has a series of problems such as backward teaching concepts, limited teaching resources, and imperfect teaching methods, which seriously restrict the development of college physical education. Therefore, under the background of "Internet +", colleges and universities need to establish a multimedia network teaching platform with more comprehensive functions and richer resources to promote the development of traditional physical education to the network teaching model, so as to improve the quality of college physical education.

\subsection{Basic structure and principle of multimedia network teaching platform}

The basic structure of the college sports multimedia network teaching platform is mainly divided into three parts: client web application, network server management, and database application analysis. First of all, the client web application is to build a sports network teaching website, so that teachers and students can log in and use freely, which can satisfy students' learning, teacher teaching resources and effective communication between students and teachers and students, and realize physical education. The diversification and liberalization of content have greatly enhanced students' participation and enthusiasm in learning. Secondly, the network server management of the multimedia network teaching platform is mainly to manage the education platform through the internal procedures of the education website, so that teachers and students can operate more freely, have a better user experience, and greatly increase the experience of teachers and students. Use stickiness to improve the effectiveness of the online teaching platform. Finally, the database application analysis behind the platform is to allow teachers to more clearly understand the main points of interest of students, help teachers to be more accurate in the design of teaching videos, and effectively improve the effectiveness of physical education online, so that teachers and students can Grow together, continuously enrich the content of online physical education, and lay a good foundation for classroom teaching.

\subsection{Main functions of multimedia network teaching platform}

According to practical teaching requirements, the college sports multimedia network teaching platform should include the following functional modules: First, the physical education resource information collation module. This part mainly plays the role of integrating online physical education teaching information, helping teachers to see the latest physical education information for the first time, and can push content according to students' hobbies, so that both students and teachers can improve efficiency in information search And accuracy. Second, the sports video teaching module. This is the core function of the multimedia network teaching platform. It can assist teaching, accurately display sports movements, analyze key sports steps, etc., so that teachers can conduct more detailed practical teaching on the Internet and ensure that students can pass online courses A deeper understanding of some difficult technical movements will encourage students to quickly grasp the relevant movements in actual offline sports, and improve the efficiency of college physical education. Third, the instant messaging module inside the platform. This module can realize instant contact between students, teachers and students, and teachers, effectively shortening the relationship between teachers and students, so that teachers can understand the progress of students in the first time, and it is also convenient for teachers to inform students in time. Communicate various teaching requirements in a manner that allows teaching communication to eliminate the limitation of distance and become more efficient. Fourth, other functional modules of the network platform. This part is mainly a collection of some commonly used functions, such as uploading and downloading sports teaching videos and information, verification of personal identity information, control of website management authority, etc., in order to better realize network teaching The management of the platform makes the multimedia network teaching platform more stable and efficient. 


\section{Concluding remarks}

With the continuous development of information technology, the multimedia network teaching platform has become the main direction of the teaching development of various subjects in colleges and universities in the future. Physical education teaching in colleges and universities should seize this opportunity to realize the transformation from traditional teaching to network teaching. Schools, teachers, and students The parties should work together to build a good online learning environment, and improve the multimedia network teaching platform through continuous experience accumulation, so as to improve the quality of college physical education and cultivate more high-quality professional talents.

\section{References}

1. Chen Yonghao. Application of sports multimedia network platform under the background of Internet+[J]. Automation and Instrumentation, 2018, 000(004):39-41.

2. Xie Chengchao. Research on the reform of physical education teaching under the background of the "Internet +" era [J]. New Education Era Electronic Journal (Student Edition), 2019, 000(032): P.1-2.

3. Li Yunpeng. Innovative exploration of college physical education in the Internet + era[J]. Journal of Minnan Normal University: Natural Science Edition, 2019, 032(003): P.81-84. 